\title{
Species Mixing Effects on Forest Productivity: A Case Study at Stand-, Species- and Tree-Level in the Netherlands
}

\author{
Huicui Lu ${ }^{1,2, *(\mathbb{D}}$, Godefridus M. J. Mohren ${ }^{1}{ }^{(}$, Miren del Río $\left.{ }^{3,4}{ }^{(}\right)$, Mart-Jan Schelhaas ${ }^{5}{ }^{(}$, \\ Meike Bouwman ${ }^{1}$ (D) and Frank J. Sterck ${ }^{1}$ \\ 1 Forest Ecology and Forest Management Group, Wageningen University and Research, Wageningen 6700, \\ The Netherlands; frits.mohren@wur.nl (G.M.J.M.); meike.bouwman@wur.nl (M.B.); \\ frank.sterck@wur.nl (F.J.S.) \\ 2 Faculty of Forestry, Qingdao Agricultural University, Qingdao 266000, China \\ 3 Department of Silviculture and Forest Management, INIA, Forest Research Centre, Madrid 28040, Spain; \\ delrio@inia.es \\ 4 Sustainable Forest Management Research Institute UVa-INIA, Madrid, 34004, Spain \\ 5 Wageningen Environmental Research, Wageningen University and Research, Wageningen 6700, \\ The Netherlands; martjan.schelhaas@wur.nl \\ * Correspondence: huicui.lu@qau.edu.cn; Tel.: +86-188-5322-8820
}

Received: 1 November 2018; Accepted: 9 November 2018; Published: 17 November 2018

\begin{abstract}
Many monoculture forests have been converted to mixed-species forests in Europe over the last decades. The main reasons for this conversion were probably to increase productivity, including timber production, and enhance other ecosystem services, such as conservation of biodiversity and other nature values. This study was done by synthesizing results from studies carried out in Dutch mixed forests compared with monoculture stands and evaluating them in the perspective of the current theory. Then we explored possible mechanisms of higher productivity in mixed stands, in relation to the combination of species, stand age and soil fertility, and discussed possible consequences of forest management. The study covered five two-species mixtures and their corresponding monoculture stands from using long-term permanent forest plots over multiple decades as well as two inventories (around 2003 and 2013) across the entire Netherlands. These forest plot data were used together with empirical models at total stand level, species level and tree level. Overyielding in Douglas-fir-beech and pine-oak mixtures was maintained over time, probably owing to the intensive thinning and was achieved on the poorer soils. However, this overyielding was not always driven by fast-growing light-demanding species. On individual tree level, intra-specific competition was not necessarily stronger than inter-specific competition and this competitive reduction was less seen at lower soil fertility and dependent on species mixtures. Moreover, size-asymmetric competition for light was more associated with tree basal area growth than size-symmetric competition for soil resources. Overall, this study suggests a substantial potential of species mixing for increasing productivity and implies developing forest management strategies to convert monospecific forests to mixed-species forests that consider the complementarity in resource acquisition of tree species.
\end{abstract}

Keywords: overyielding; periodic annual volume increment; basal area increment; inter- and intra-specific competition; mixed forest

\section{Introduction}

Forests provide multiple ecosystem services to society. In Europe, forest managers have changed their focus for different services dramatically over the recent past. Starting from the middle of the 
19th century, forest managers strongly favoured an economic approach to achieve maximum and constant annual yield. There was a focus on increasing even-aged coniferous plantations by reducing the numbers of broadleaved trees and the area of uneven-aged forests [1,2]. However, the coniferous monocultures were often negatively affected by climate change [3], insects and natural disturbances, such as windthrow [4], and they often degraded soils and decreased site productivity. By the end of the 20th century, forest managers started to convert many conifer monoculture plantations into mixed species forests, sometimes together with broadleaved species. This transition towards more mixed forests became a common practice in many areas of Europe [5], including the Netherlands [6], and served several purposes, for example, increasing the productivity, stability, resistance and resilience of forests [7-10].

Currently, European forests (without the Russian Federation) cover about 215 million ha, i.e., $33 \%$ of Europe's land area by 2015 [11]. Most forests in Europe are still made up of predominantly coniferous stands (45\%) and predominantly broadleaved stands (36\%). The remaining $19 \%$ are stands that are co-dominated by coniferous and broadleaved species. In the Netherlands, forests cover a relatively small area, with only about $11 \%$ (373,480 ha) of total land surface [12]. In this forest area, slightly over $21 \%$ is dominated by conifers, $21 \%$ by broadleaved species, and the remaining by mixtures of conifer and broadleaved species. Most Dutch forests are even-aged (62\%) and are of intermediate age, with an average age of 67 years for conifers and 55 years for broadleaved species forests. The share of uneven-aged forests is small with $16 \%$ and special forest, such as coppice or park forest occupies $24 \%$. Despite the importance of mixed forests in the Netherlands, there is little information about stand dynamics and productivity of the prevailing mixtures, as well as about the best forest management alternatives for these stands.

In this study, we focus on productivity of Dutch even-aged stands comparing monospecific and mixed stands at different scales, from stand to species and tree levels. We compile results of three specific studies on mixing effects on productivity in Dutch forests previously performed by us, with two of them already published $[13,14]$. These studies explored how species mixing affects productivity and how complementary resource use may contribute to this, by focusing on Dutch forests differing in species compositions, stand developmental stages and site conditions. Analysing these patterns can advance our understanding of when, where and why mixed-species forests may have higher productivity compared with monoculture forests. This information may provide relevant knowledge to adapt silvicultural guidelines and management tools developed for monospecific stands to mixed stands, as a first step to improve forest management in mixed forests [15].

First, in this Introduction, we briefly review the main concepts and theories on species interactions, under the context of Dutch forests, and describe our main research questions and hypotheses. Then, we summarise the material and methods applied in the abovementioned three specific studies. Finally, we show and discuss the main results from these studies, including some suggestions for management of mixed forest.

\subsection{Limiting Factors and Resource Acquisition in Mixed-Species Forests}

When mixed forest plantations/stands use resources more efficiently, this may result in higher production compared to their respective monocultures. This phenomenon is often referred to as overyielding [16]. Overyielding may be affected by many factors, including differences in species composition, stand developmental phases, environmental conditions, forest management practices, climate change and other factors [3,17-19], as shown in Figure 1. The niche complementarity hypothesis $[16,20]$ states that different species in mixed forests can have complementary above- and/or belowground resource acquisition and use. Species differences in crown architecture, shade tolerance, leaf phenology and root distribution may contribute to such complementarity and thus lead to higher productivity, i.e., overyielding, which are shown in Figure 1, and further explained below. 


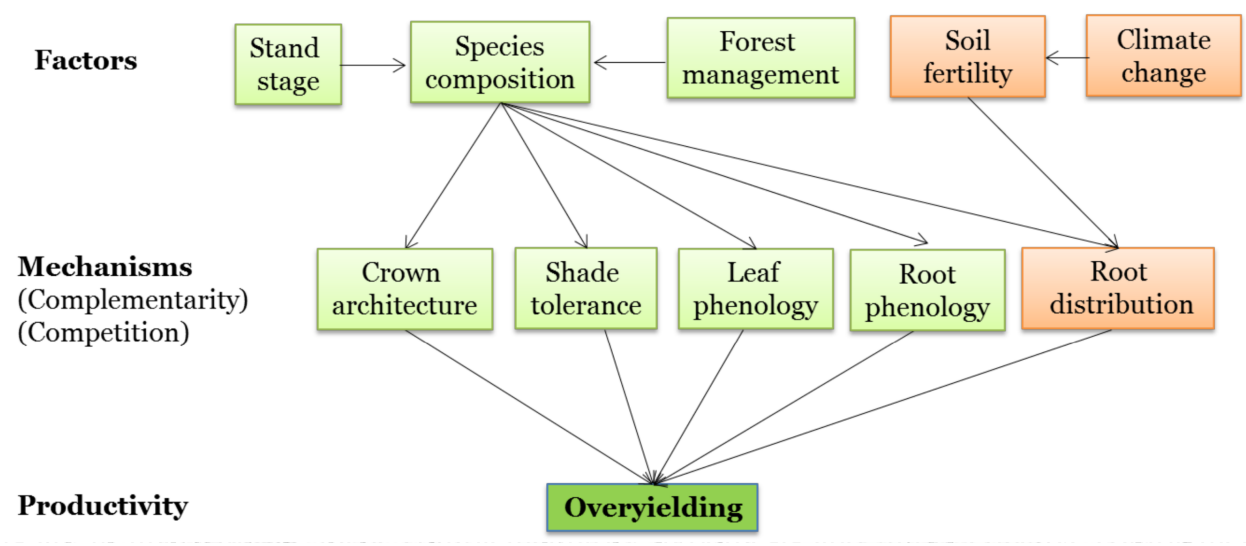

Figure 1. Conceptual framework representing factors and possible main mechanisms that could influence overyielding. The mechanisms are due to complementarity or reduced competition for light and soils.

In mixed forest stands, trees of fast-growing light-demanding species and shade-tolerant species can occupy different layers of the canopy. Consequently, multiple crowns of different species better fill the above ground space, and result in higher light absorption and light use efficiency [21,22]. On top of that, total annual light absorption might increase when species differ in leaf phenology. If deciduous species co-occur with other deciduous tree species, those trees compete for light during the summer. However, mixing evergreen conifers and deciduous species, trees of evergreen species may capture and use light in autumn and early spring when deciduous trees are without leaves. The elongated overall leaf life span of the forest through the year may allow for complementary light use and result in higher productivity [23]. In addition, plasticity in crown architecture has been shown to increase canopy packing $[21,22,24]$, and this complementarity in using space is observed to result in overyielding in mixtures by increasing both overall light interception and/or light use efficiency [25]. These studies thus imply a strong potential for aboveground complementary light use in mixed forests.

Belowground, differential root distribution is considered an important potential mechanism for overyielding. A growing number of studies shows that fine root productivity was higher in mixed-species stands compared with their monoculture stands [26-29]. Several processes may be associated with explaining this higher fine root productivity. First, the soil resources acquisition could be enhanced if mixing shallow-rooted species dominating the top soil with deep-rooted species spreading into deeper soil layers [28,30-33]. This vertical root stratification can also enhance soil resource availability, by hydraulic lift of soil water [34]. Secondly, more evenly distributed roots increase horizontal soil volume filling due to intense root interactions to increase resource foraging in mixtures than monoculture stands [26,29]. Thirdly, the facilitative effect of nitrogen-fixing species on the growth of non-nitrogen-fixing species may cause overyielding, particularly when nitrogen is more limiting [35]. Lastly, nutrient cycling could be accelerated because of the existence of fast nutrient cycling species. Increases in nutrient availability can lead to more root growth and the carbon can then be used for stem growth [36].

\subsection{Below Versus Aboveground Species Interactions in Complementary Resource Use}

The belowground complementary resource use may depend on soil fertility. Here, it is important to note that two dominant hypotheses depict the changes in species interactions with soil fertility, with possible consequences on overyielding. The stress-gradient hypothesis suggests that species interactions in plant communities change from competition at high soil fertility to facilitation or better belowground complementary resource use at low soil fertility [37]. The resource-ratio hypothesis states that species interactions run from competition for light at high soil fertility to competition for soil resources at low soil fertility [38].

Many studies show that overyielding occurred on poor sites and underyielding, i.e., mixed-species forests grow slower than the corresponding monocultures under the same growing conditions [16], 
or no species mixing effect appeared on richer sites [39-41]. To the contrary, other studies document stronger overyielding on rich sites, and suggested that this was due to stronger complementarity [42-45], confirming the resource-ratio hypothesis. These contrasting findings may arise from environmental conditions, forest management practices, and other factors. On the poorest soils in Dutch forests, only a limited number of species occurs and the potential for productivity gain by mixing species is unsure.

Similarly, several studies demonstrate strong competitive interactions at tree level in favourable growing seasons and more complementarity effects in years of poor growing conditions [46-48]. Tree level analyses on species interactions which split competition in size-symmetric/size-asymmetric and intra-/inter-specific components have been found to provide significant insights on below vs. aboveground interactions $[49,50]$. A number of studies identified the competition for light as size-asymmetric since larger individuals take more than their (size-) proportional share of intercepted light compared to smaller individuals. Instead, the competition for belowground soil nutrients and water is considered size-symmetric for all the individuals, implying that trees take their (size-) proportional share of soil resources [51,52].

\subsection{Stand Age and Management Effect on Mixing Effects}

At young stand age, small trees of fast-growing light-demanding species capture light more efficiently and grow more rapidly than trees of more slow-growing shade-tolerant species. Once fully occupying the growing space and closing their canopy, the competition for light increases. The trees of light-demanding species dominating the upper canopy may transmit sufficient light for trees of shade-tolerant species to survive and grow [53]. The forest productivity in even-aged stands typically changes with stand development, reaching a peak at early forest age, followed by a substantial decline, probably due to the increasing costs of maintaining living wood or due to hydraulic limitations [54]. Yield tables also show this productivity pattern in even-aged monocultures in the Netherlands, and it is well understood that this pattern varies with site conditions [55]. In some studies, it was observed that stem and fine root productivity increased with increasing stand age, in both temperate and boreal mixed forests [26,44], but overyielding effect decreased after certain ages [56]. All those studies presented long-term, multiple decades of observations rather than single point, or data collected during short periods. The scarcity of long-term data is one of the probable reasons for uncommon studies on species mixing effects on stand productivity with stand development. In this study, the species mixing effect on productivity with stand development is evaluated by using data from long-term permanent field plots from the Netherlands.

Stand density may also influence growth and species interactions in mixed-species forests. Stand growth usually increases with density initially before levelling off at higher densities, but at very high densities competition may outweigh complementary effects, thus the overyielding effect [17]. In those Dutch forests, species interactions are continuously affected by forest management practices, in both monocultures and mixtures. Under given environmental conditions and tree species compositions, forest management aiming at increasing forest productivity often uses thinning to reduce the stand density [57], thus increasing the availability of light, water, and nutrients for the remaining trees. This situation differs from most of the existing studies, which focussed on mixed forests where thinning operations were not applied to assess the mixing effect on productivity $[9,39,40]$. Thinning may modify the mixing effect by reducing the competition.

\subsection{Research Questions and Hypotheses}

In this study, productivity is compared between mixed forest stands and corresponding monoculture stands. Differences in productivity between mixtures and monocultures are explained from differences in tree attributes (crown architecture, shade tolerance, leaf phenology, and root distribution) between species, which reflect different mechanisms of complementarity. In addition, how these trends can be affected by stand age, soil fertility and forest management is discussed (Figure 1). 
The specific research questions are:

- What is the effect of species mixing on stand productivity with stand development?

- How does overyielding depend on the attributes of mixed species along a soil fertility gradient?

- What is the effect of competitive interactions on tree growth in mixed-species forests along a soil fertility gradient?

The hypotheses corresponding to these questions are:

- In line with the niche complementarity hypothesis, it is expected that tree species of mixed stands that differ in leaf phenology and/or shade tolerance overyield more strongly. Second, it is expected that overyielding decreases with stand development because fully grown stands take all resources and limit resource partitioning (Figure 2a). However, in thinned stands, resource partition may maintain with age and thus offset trends in overyielding.

- It is hypothesised that the faster growing and more light-demanding species would dominate the slower growing and more shade-tolerant species in mixed-species stands, and that complementary use of light by these two species causes overyielding. Second, according to the stress-gradient hypothesis, overyielding by complementary soil resource use would be stronger at poor soils than at rich soils (Figure $2 b$ ). Alternatively, following the resource-ratio hypothesis, overyielding would be stronger at rich soils.

- First, it is predicted that intra-specific competition is stronger than inter-specific competition and the competitive reduction is greater at less fertile soils, in accordance with the stress-gradient hypothesis. Second, when light is the most important growth limiting factor in Dutch forests, size-asymmetric competition for light is more relevant for tree growth than size-symmetric competition for soil resources. Third, given that forests develop a denser canopy, size-asymmetric competition will be greater at high fertility soils, in accordance with the resource-ratio hypothesis, and this in turn may imply a higher probability of complementarity for light than for soil resources (Figure 2c).

(a)

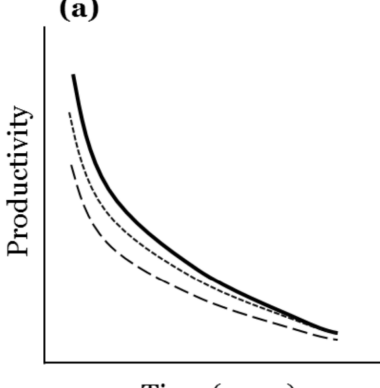

Time (years) (b)

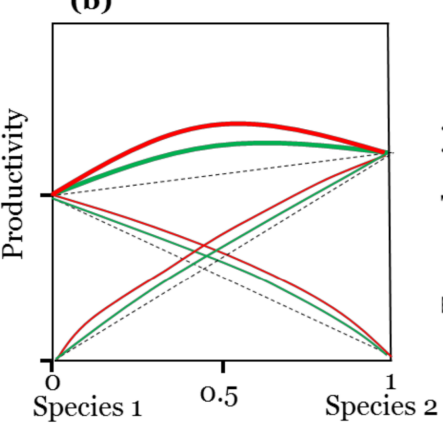

(c)

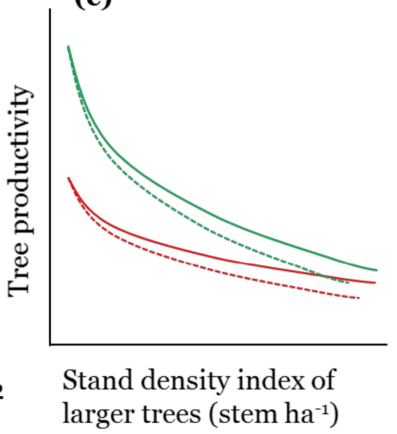

Figure 2. Conceptual diagram for the hypotheses in this study: (a) productivity expressed as stand volume growth in a mixture versus their respective monocultures over time; (b) productivity expressed as volume growth of a mixture and their respective monocultures, and in relation to the species proportions within the mixture; and (c) productivity expressed as tree basal area growth changes with stand density index of larger trees. (a) The dashed lines represent two monoculture stands, and the solid line represents a mixture composed of the two corresponding species. (b) Dashed lines represent predicted values with null mixing effect, i.e., no overyielding. The solid red lines represent predicted values with stronger overyielding on poor soils, and the solid green lines represent the less overyielding at richer soils. Note that those predictions differ between the stress-gradient hypothesis and the resource-ratio hypothesis. (c) The red and green lines represent the tree basal area growth with stand density index of larger trees in mixed stands at poor soils and at rich soils, respectively. The solid and dashed lines represent the same and different intra- and inter-specific competition in mixed-species stands, respectively. The decrease in tree productivity is larger with stand density when soil fertility is richer, meaning stronger competition for light at rich soils. 


\section{Methods}

In this study, data were taken from two datasets of forests across the Netherlands. One dataset consists of growth and yield data (GYD) from permanent field plots [58] and the other is the Dutch national forest inventory (NFI) data [12]. The GYD contains information of stand development of 319 plots in monoculture from 1929 to 2011, and of 91 plots in mixture between 1949 and 2004. Five tree species in monoculture are included: Douglas-fir (Pseudotsuga menziesii (Mirb.) Franco), common beech (Fagus sylvatica L.), Scots pine (Pinus sylvestris L.), pedunculate oak (Quercus robur L.) and silver birch (Betula pendula Roth). In two-species mixtures, they occur in the following combinations: Douglas-fir-common beech, Scots pine-pedunculate oak, pedunculate oak-common beech, and pedunculate oak-silver birch. Number of plots, plot age, stand density are shown in Table 1, for more plot information see tables in our previous work $[13,14]$. These plot data were used to show how species mixtures influence forest stand productivity during stand development at stand level [13]. In addition, it was used to show how the productivity of individual species in mixtures compared to their monocultures, and how such species-specific productivity was affected by soil fertility at species level [14].

Table 1. Stand and plot characteristics for this study.

\begin{tabular}{|c|c|c|c|c|c|}
\hline Species & $\begin{array}{l}\text { Number of } \\
\text { Plots }\end{array}$ & Plot Size (ha) & $\begin{array}{l}\text { Age Span } \\
\text { (years) }\end{array}$ & $\begin{array}{c}\text { Survey Duration } \\
\text { (years) }\end{array}$ & $\begin{array}{c}\text { Stand Density } \\
\text { (trees/ha) }\end{array}$ \\
\hline \multicolumn{6}{|l|}{ Growth and yield data } \\
\hline \multicolumn{6}{|l|}{ Pure stands } \\
\hline Douglas-fir & 114 & $0.008-0.290$ & $6-130$ & 1929-2011 & $63-5781$ \\
\hline Common beech & 39 & $0.008-0.198$ & $16-176$ & 1960-1999 & $60-3671$ \\
\hline Scots pine & 72 & $0.008-0.156$ & $16-150$ & 1954-1999 & $129-14450$ \\
\hline Silver birch & 22 & $0.008-0.090$ & $7-125$ & 1984-1999 & 224-2927 \\
\hline \multicolumn{6}{|l|}{ Mixed stands } \\
\hline Fir-beech & 17 & $0.032-0.315$ & $11-108$ & 1984-2003 & $84-6012$ \\
\hline Pine-oak & 30 & $0.016-0.400$ & $12-160$ & 1949-2004 & $152-13789$ \\
\hline Oak-beech & 18 & $0.008-0.198$ & $19-265$ & 1984-1999 & $106-2753$ \\
\hline Pine-oak & 53 & $0.005-0.102$ & $14-124$ & 2004-2013 & $167-2674$ \\
\hline Pine-birch & 55 & $0.008-0.102$ & 9-121 & 2004-2013 & $210-3311$ \\
\hline
\end{tabular}

Data are from minimum to maximum. NFI data: Dutch national forest inventory data.

The Dutch NFI data provide a shorter time series, with one re-census after 2003 in the period between 2011 and 2013, and thus provide information of stand productivity over a period of maximum 10 years, from plots distributed all over the Netherlands. From the Dutch NFI data, 145 plots with mixed species were selected including three mixtures: pedunculate oak-silver birch, Scots pine-pedunculate oak, and Scots pine-silver birch (Table 1). The Dutch NFI data were used to show the consequences of competitive interactions on growth of trees in forest stands differing in stand density and soil fertility. To examine whether individual tree growth is better explained by size-asymmetric or size-symmetric competition, the tree-level models considered competition with all individuals (as a proxy of size-symmetry, expressed by Reineke's stand density index, SDI) or only larger individuals (as a proxy of size-asymmetry, SDI of larger trees, SDIL [50]). Size-asymmetric competition for light and size-symmetric competition for soil resources were separated in the analysis to show possible complementary impacts on productivity in mixed forests. The combination of stand-, species- and tree-level analyses allows for better understanding of mixing effects on forest productivity and forest functioning [59], and can indicate potential sources of error when comparing measurements of a given processes at different levels and when scaling up or down between each level [60].

Additionally, these plot data from the two datasets were coupled with soil data using the ISRIC-World Soil Information SoilGrids250m database [61]. Forest plots from both datasets come 
mainly from sandy soils areas, and cover a natural soil fertility gradient on sandy soils within the Netherlands. Hereafter, the five species and monocultures are written as Douglas-fir, beech, pine, oak and birch, and the five mixtures accordingly as Douglas-fir-beech, pine-oak, oak-beech, oak-birch and pine-birch, respectively. The locations of the selected forest plots are shown in Figure 3.

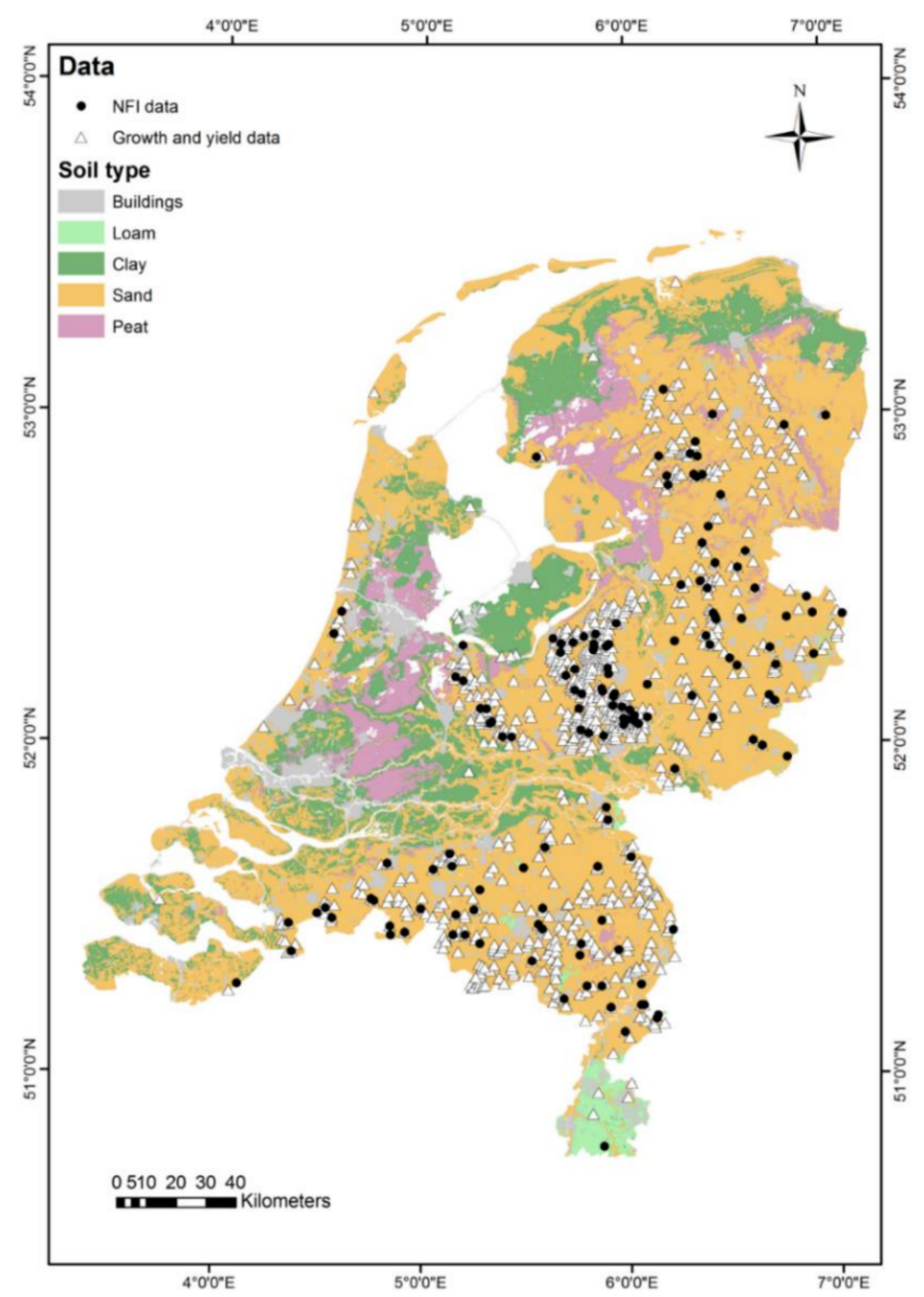

Figure 3. Distribution of the studied plots throughout the Netherlands [62]. Growth and yield data: from long-term permanent field plots; NFI data: Dutch national forest inventory data.

\section{Results and Discussion}

\subsection{Complementarity in Light Use}

The observation in long-term permanent plots showed that overyielding occurred in both evergreen-deciduous studied mixtures (Douglas-fir-beech and pine-oak), but not in the deciduous-deciduous mixtures (oak-beech and oak-birch) [13]. The results suggest that differences in leaf phenology between the mixed species can contribute to higher productivity, or overyielding. Moreover, the overyielding was even stronger for the evergreen-deciduous species mixture with the largest difference in shade tolerance (Douglas-fir-beech), implying that differences in shade tolerance may be important too (Figure 4). Trees of fast-growing species grow rapidly and may establish a more favourable position in the canopy compared to trees of slow-growing species which are often more shade tolerant $[63,64]$. Such differences in height growth allow light-demanding species to occupy the upper layer of the canopy and may leave the shade-tolerant species in a lower layer, thus creating a canopy with multiple crown layers (Figure 5). Such a multi-layered canopy may be more effective in light 
absorption and hence in light use efficiency [21,22]. The vertical distribution in tree height might change over time through tree growth, regular mortality, natural disturbances and forest management $[65,66]$. Our data show two distinct species layers in the two evergreen-deciduous species mixtures across the studied ages (Figure 5a,b), while such stratification was much weaker for deciduous-deciduous forests (Figure $5 c, d$ ). These distinct canopy layers of the two evergreen-deciduous species mixtures over time might explain the overyielding over different stand ages. Our results are in line with the niche complementarity hypothesis and imply effective complementary light use in evergreen-deciduous species stands, particularly when the two species differ in shade tolerance.
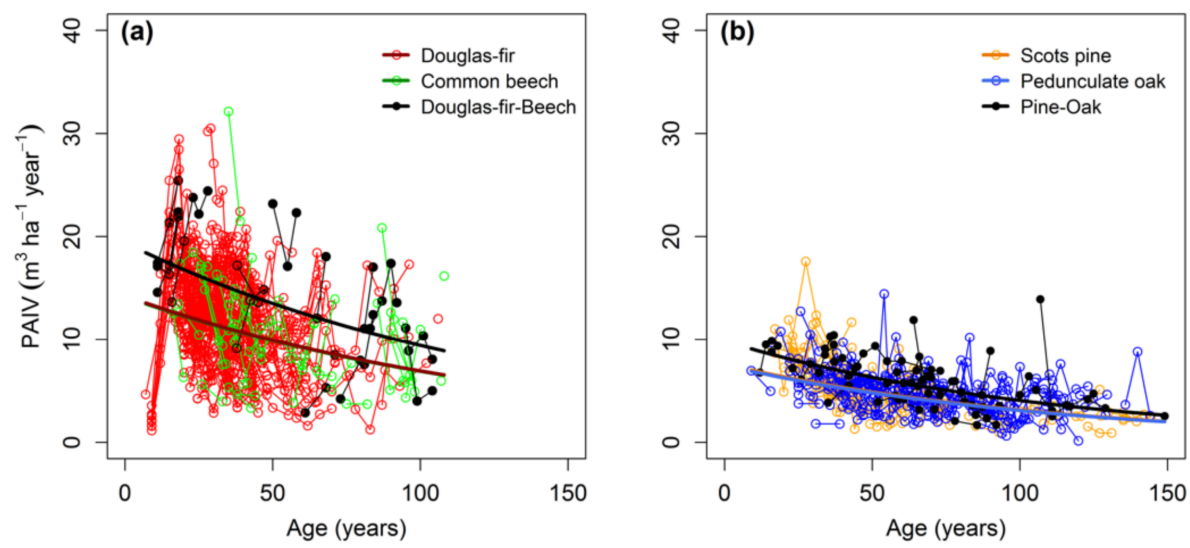

Figure 4. Periodic annual volume increment (PAIV) in mixtures and corresponding monocultures over time. (a) PAIV in Douglas-fir, common beech monocultures and Douglas-fir-common beech mixtures, respectively. (b) PAIV in Scots pine, pedunculate oak monocultures and Scots pine-pedunculate oak mixtures, respectively. For these results and two other mixtures see our previous results [13].
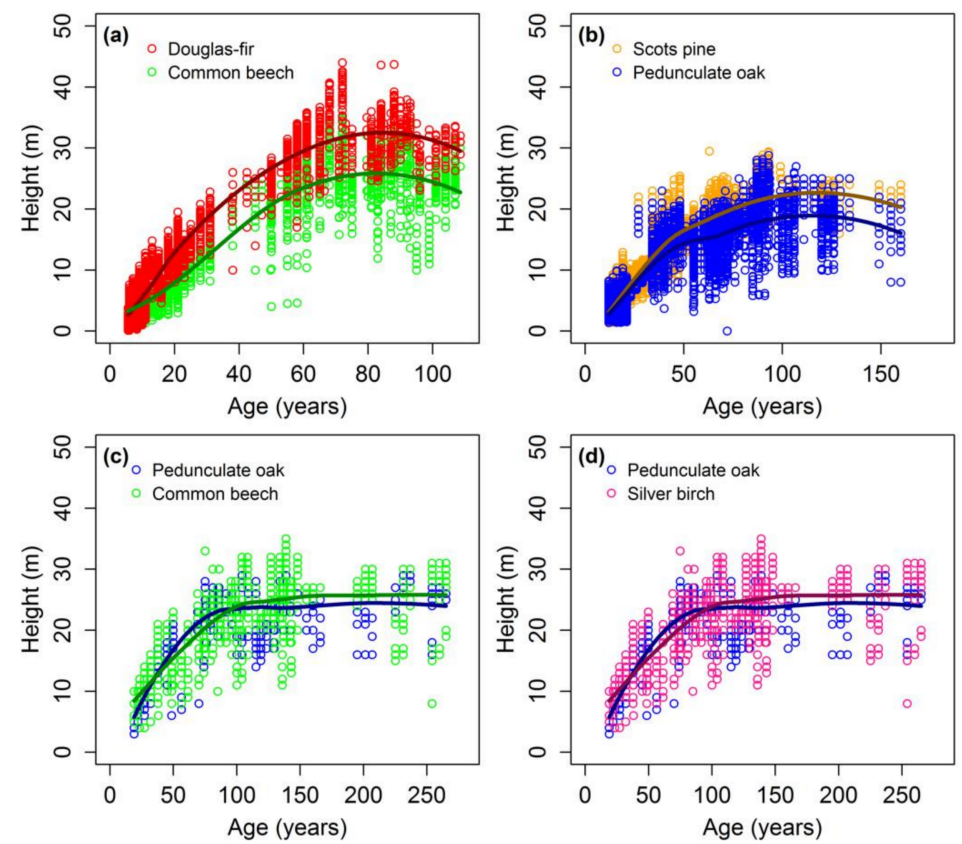

Figure 5. Tree height over time in four two-species mixtures derived from growth and yield data from permanent field plots in this study [14]: (a) mixed stands of Douglas-fir and common beech; (b) mixed stands of Scots pine and pedunculate oak; (c) mixed stands of pedunculate oak and common beech; and (d) mixed stands of pedunculate oak and silver birch. Solid lines indicate the average height for each of the species over time. 
In addition, the improved light interception and/or light use efficiency might be further supported by differences in species crown architecture. Crown complementarity has been shown to increase canopy packing and thus contribute to overyielding [21,22,24,25]. We did not have data describing crown properties, but used tree height in the mixed forest as an indicator for canopy stratification, as discussed above.

\subsection{Effect of Age and Forest Management}

We expected that overyielding decreases with stand development because fully growing stands take all available limiting resources and limit resource partitioning between different species. In contrast with our hypothesis, stand age had no significant effect on the overyielding in the two evergreen-deciduous species mixtures (Douglas-fir-beech and pine-oak). It can be argued that forest management by thinning may keep stands relatively open, as indicated by the relatively low basal areas [13]. The forest stands studied here, may therefore never close completely and may have resources and growing space available for complementary use by the other species. Another study has even shown that overyielding in mixtures of Douglas-fir and beech increased with stand development [44]. These authors argued that there was a shift of competition strength between the two species along the age gradient. After 15 years, Douglas-fir outcompeted beech and the difference in height triggered larger diameter growth of Douglas-fir, thereby resulting in increasing overyielding during stand development $[32,44]$. These studies imply that overyielding occurs especially later during stand development. We argue that the thinning regime is responsible for this in both cases. Our constant overyielding over time could be partially explained by the lack of data for young forest stand in our data base ( $<15$ years old were absent). Moreover, in our analysis, we kept the possible forest management effects on overyielding, rather than removing the plots that had been managed during the last five years $[9,39,40]$. In conclusion, overyielding appears to be maintained with stand age in the heavily managed forests stands in the Netherlands, and the management of forests by thinning is likely to play a key role in this.

\subsection{Soil Impact}

We found stronger overyielding in Douglas-fir-beech and pine-oak stands on low fertility soils than on fertile soils (Figure 6) [14]. Hence, our results support the stress-gradient hypothesis and not the resource-ratio hypothesis at first sight, suggesting there was complementary soil resource use at low soil fertility. This complementarity may be due to different root distributions in mixed-species stands. Previous empirical studies have reported that overyielding increased [42-44] or decreased [39,41,67] with improving site conditions. This divergent finding may arise from different growth-limiting factors. In our study, low fertility soil of Dutch forest might still allow for sufficient stand productivity and dense canopies. With canopy being less dense at low soil fertility, the competition for light may be less and maybe allow trees of different species to partition light more effectively than in the crowded, denser canopies on rich soils. Therefore, low fertility soil allows for complementary soil resource use, but can also allow for complementary light use, and both may promote aboveground stem growth. This implies that complementary use of both light and soil resource can act as potential drivers underlying the stronger overyielding in stands on lower fertility soils. 

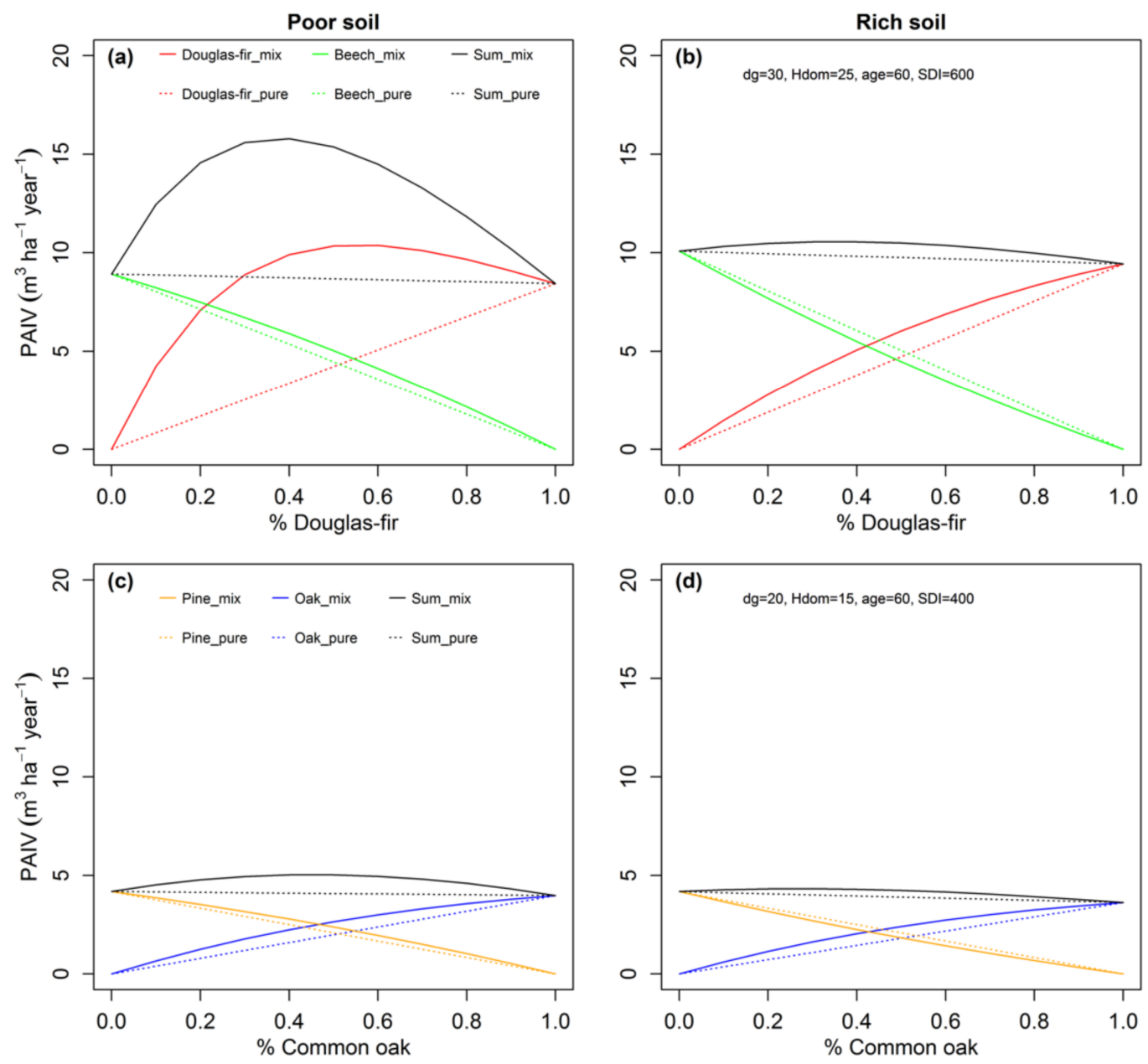

Figure 6. Periodic annual volume increment (PAIV) in mixed and pure stands on poor (a,c) and rich soils $(\mathbf{b}, \mathbf{d})$, given the admixture proportion, mean values of quadratic mean diameter $(\mathrm{dg})$, dominant height (Hdom), age, stand density index (SDI). (a,b) Douglas-fir and beech growing in pure and Douglas-fir-beech mixed stands. (c,d) Pine and oak growing in pure and pine-oak mixed stands. For poor and rich soil definitions and results of another two mixtures see our previous results [14].

\subsection{Intraspecific Competition Stronger than Interspecific Competition?}

We examined the competitive interactions in mixed stands (oak-birch, pine-oak, and pine-birch) on individual tree growth growing on soils differing in fertility based on NFI data. We hypothesized that intra-specific competition is stronger than inter-specific competition and that the competitive reduction is more pronounced at low fertility soils, in accordance with our earlier results [14], which means that the decrease in tree basal area growth resulting from competition is smaller at lower soil fertility (Figure 2). We showed that for the studied species in the three mixtures, intra-specific competition was larger than inter-specific competition for birch in oak-birch and pine-birch mixtures, as well as for oak in oak-birch mixtures. However, no significant differences were found between the impact of intra- versus inter-specific competition for pine in pine-oak and pine-birch mixtures or for oak in pine-oak mixtures. The effect of competitive reduction was smaller with improving soil fertility for birch in pine-birch mixtures, but independent of soil fertility for oak and birch in oak-birch mixtures (Figure 7). The results were thus different for different stands and species mixtures, and we therefore did not find evidence for general support for either the stress-gradient hypothesis or resource-ratio hypothesis. Other studies found that the species complementarity led to more tree growth because of lower inter- compared to intra-specific competition [49,50], but also concluded that this might depend on soil fertility, stand age and species composition $[39,68,69]$. In short, intra-specific 
competition is not necessarily stronger than inter-specific competition in mixed forests, and may depend on the species compositions of the mixtures under study.
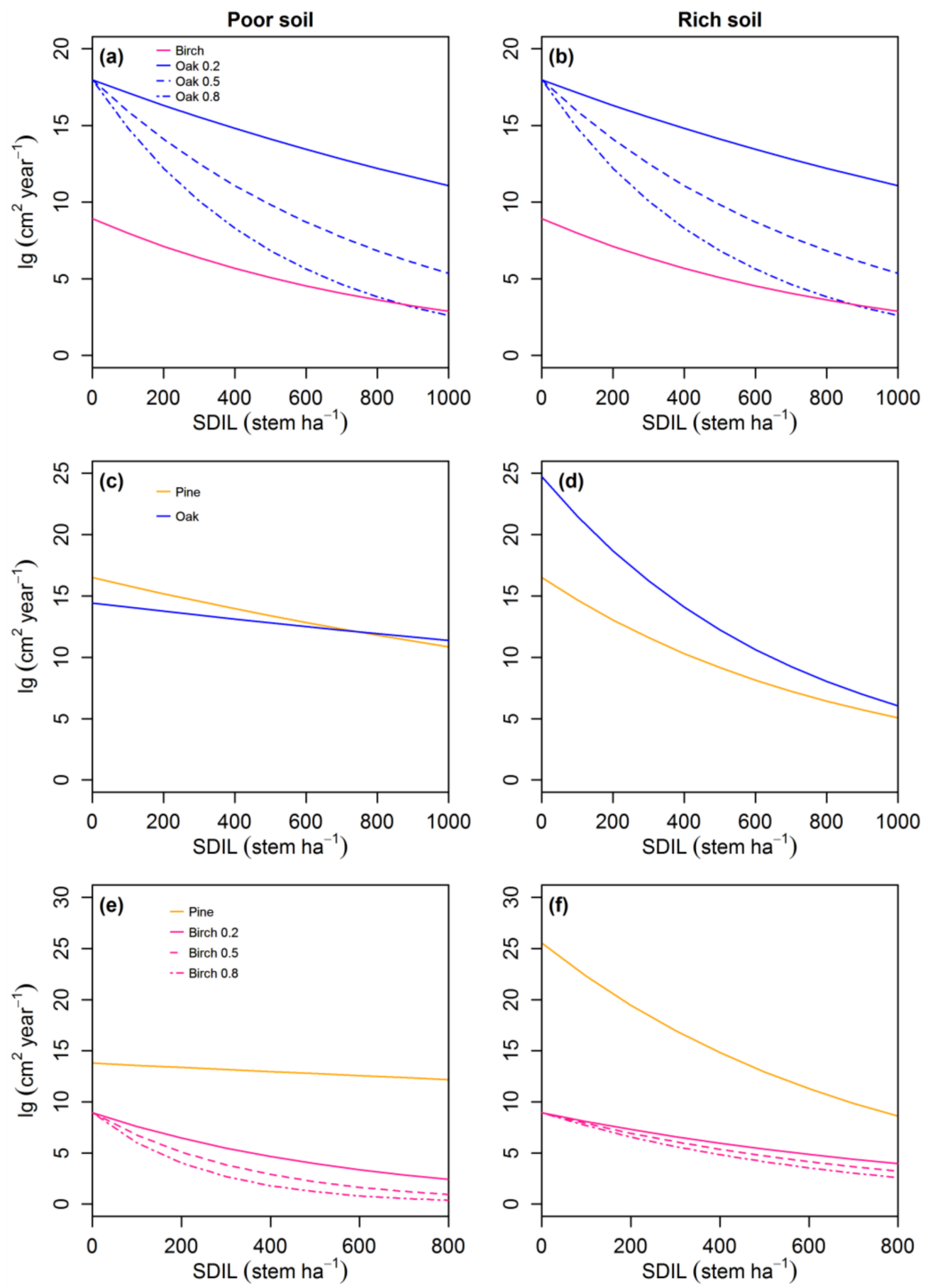

Figure 7. Tree basal area growth (Ig) changes with stand density index of larger trees (SDIL) on: poor soil $(\mathbf{a}, \mathbf{c}, \mathbf{e})$; and rich soil $(\mathbf{b}, \mathbf{d}, \mathbf{f})$. (a,b) Oak and birch in oak-birch mixtures depending on oak proportion in stand density index of larger trees (SDILoak/SDIL) for an oak tree of diameter $23.8 \mathrm{~cm}$ with SDIL $=190$ stem ha ${ }^{-1}$. (c,d) Pine and oak in pine-oak mixtures at poor site and at rich site. (e,f) Pine and birch in pine-birch mixtures depending on birch proportion in stand density index of larger trees (SDILbirch/SDIL) at poor site and at rich site. 


\subsection{Competition for Light or for Soil Resources?}

We expected that, when light is the most important growth limiting factor, size-asymmetric competition for light is more relevant for tree growth than size-symmetric competition for soil resources. As expected, size-asymmetric competition for light was shown to be more associated with tree growth than size-symmetric competition for soil resources (Figure 7), suggesting that light is the most limiting resource. We further expected that since forests may establish a denser canopy at rich soils, size-asymmetric competition is larger at rich soils compared to poor soils following the resource-ratio hypothesis, and in turn this may allow for complementary light use rather than for more efficient soil resource use. We found that this effect was stronger at high soil fertility for pine in pine-oak and pine-birch mixtures, and for oak in pine-oak mixtures (Figure 7), which supports the resource-ratio hypothesis. However, this effect was not observed for birch in pine-birch mixtures since this species showed a smaller effect of competition for light at high soil fertility, and the effect was independent of soil fertility for oak and birch in oak-birch mixtures.

Our results were consistent with studies that found stronger competition for light at rich soils $[17,43,70]$, but weaker competition for light on high fertility soils was also reported in the literature [68,71]. Our results are in line with some studies in temperate forests that found that competition for light was more relevant for tree growth than competition for soil resources $[17,43]$. However, other studies revealed that in terms of tree growth, the effects of competition for light or for soil resources differ depending on the competing species $[50,68,72]$. In the end, this complementary light use at tree level might improve individual tree growth and drive higher stand productivity in mixed forests stands, i.e., lead to overyielding. However, the tree level cannot always be directly extrapolated to stand level [73], and future research should clarify the dynamic process of species interaction in various types of mixtures along soil fertility gradients.

More importantly, mixing effects on root growth could also be modified by soil fertility, and mixing effects may influence soil fertility by affecting litter decomposition. However, experiments about species mixing on root distributions and litter decomposition in temperate forests remain scarce, and are almost absent for soil fertility gradients. We call for further study on this aspect to uncover the species mixing effect on root distribution and litter decomposition, and in turn, possible impacts on overyielding.

\subsection{Revisiting the Stress-Gradient Hypothesis and the Resource-Ratio Hypothesis}

The stress-gradient hypothesis and the resource-ratio hypothesis state that species interactions vary along a soil fertility gradient. The species interactions on productivity and overyielding on poor and rich soils for the stress-gradient hypothesis, resource-ratio hypothesis, and our own hypothesis based on the results reported in this study are shown as "++", "+," "-", "n.a." and "?" in Figure 8. The stress-gradient hypothesis essentially only refers to belowground soil resource use and does not explain the aboveground light use along the soil fertility gradient (n.a.). In short, the stress-gradient hypothesis predicts that complementary resource use belowground would be stronger on poor soils $(++)$ than on rich soils (-). Alternatively, the resource-ratio hypothesis predicts that complementary resource use for aboveground is stronger and the key driver of higher overyielding on richer soils, thus overruling possible complementary for belowground resources on poor soils. Our results, however, suggest that overyielding of mixed forests is stronger on poor soils than on rich soils, as predicted by stress-gradient hypothesis but not by resource-ratio hypothesis [14]. However, our results also imply that there is stronger aboveground complementary use for light on poor soils (++) than on rich soils (+), but the role of complementary use of below ground resources remains actually largely unknown (?). 
Poor soil

Expectations from Stress-gradient hypothesis

Expectations from Resource-ratio hypothesis

Results in this study

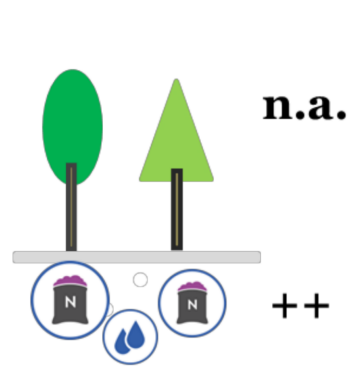

\section{Rich soil}
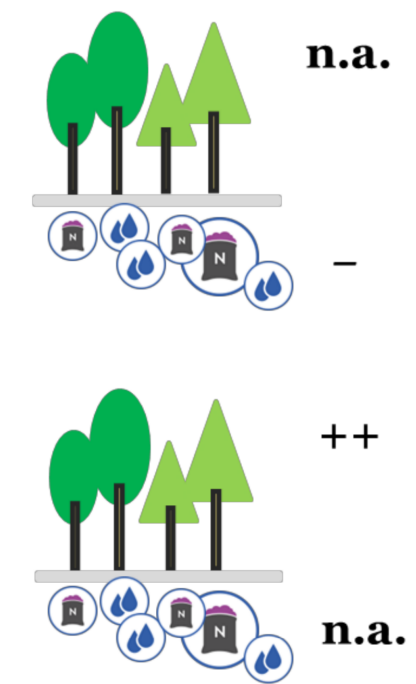

n.a.
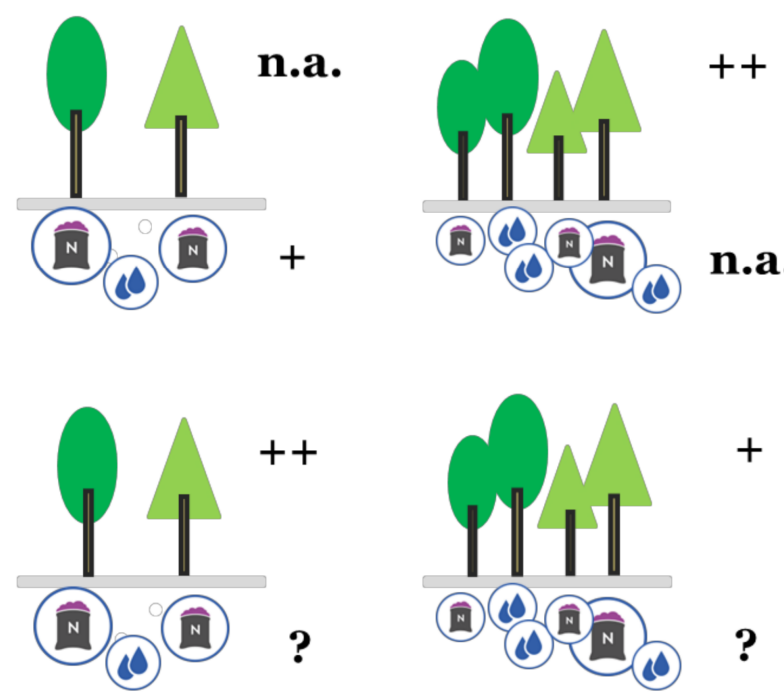

Figure 8. Schemes to illustrate the expectations and results of overyielding effects on soils contrasting in fertility (poor and rich soils) according to the concept of competition and complementarity from the stress-gradient hypothesis and resource-ratio hypothesis, and a newly formulated hypothesis based on the results of this study. Number of trees indicates the canopy density: more trees, denser canopy. The signs "++", "+", "-", "n.a.", and "?" refer to above- and belowground complementary effects: ++ , stronger complementary; +, weaker complementarity; - , no complementarity; n.a., not applicable; ?, unknown. Soil sketch adapted from [74].

Our results at stand level and species level suggest that the mechanisms for complementary soil resource use are stronger on poor soils. However, the competition for light was stronger on high fertility soils (Figure 7). Thus, our studies of competition among tree species do not support either of the two dominant hypotheses. Under Dutch climatic conditions, the soil conditions and climate still allow for sufficient stand productivity and dense canopies on poor soils that may better allow for complementary use of light than the denser canopies on rich soils. On higher fertility soils, trees face stronger competition for light but with reduced potential for partitioning light, which thus results in weaker overyielding than on lower fertility soils [14]. Our results and speculations thus shed new light on the stress-gradient and resource-ratio hypotheses. For mixed stands in the Netherlands, the greatest productivity gain is achieved on the poorer soils, and we argued that this is driven by complementary use of light, but with an unknown contribution of complementary use of soil resources. 


\subsection{Limitations of the Data and Approaches}

There are limitations in these data and approaches. The complementarity mechanisms (Figure 9) are not measured directly, but taken as a starting point for interpreting patterns in productivity of mixed forests. Other factors are also potentially relevant, but cannot be distinguished from these field data. For instance, root distributions and pathogen diversity were not measured but may influence the competition among individual trees [75]. Moreover, forest management is a confounding factor when comparing productivity in mixed versus monoculture stands, as thinning aims to interfere with competition to favour one species over the other. Besides, the different species compositions in the two datasets (Table 2) limit generalising the results, since the missing mixtures at stand level analysis cannot be further explored at the tree level. The three organisation levels studied (stand, species and tree) allow to show how changes at one level influence patterns at another level [60], but such links remain indirect. Keeping in mind these limitations, this study shows impacts of species mixing on productivity patterns in forests, and several hypotheses are considered to discuss underlying mechanisms.

Table 2. Overview of the use of monocultures of five species and mixtures composed with those five species in this study.

\begin{tabular}{cccccc}
\hline & Douglas-Fir & Common Beech & Scots Pine & Pedunculate Oak & Silver Birch \\
\hline Douglas-fir & & & n.a. & n.a. & n.a. \\
Common beech & $+/++$ & n.a. & & n.a. \\
Scots pine & n.a. & n.a. & & & \\
Pedunculate oak & n.a. & $-/+$ & $++/+$ & & \\
Silver birch & n.a. & n.a. & $+/-$ (potential) & $-/-$ & \\
\hline
\end{tabular}

Empirical support for overyielding of each species: $++/+,+/++,-/+,+/-,-/-$ where the first symbol refers to the species in the row, and the second symbol to the species in the column. ++ , relatively strong overyielding; + , relatively weak overyielding; - , no overyielding effect; n.a., not applicable; potential in parenthesis means higher tree growth of both species.

As illustrated in Figure 9, in line with niche complementarity hypothesis [16,20], mixed tree species differing in leaf phenology and shade tolerance contributed to overyielding due to complementary light use. Differences in crown architecture might have also played a role in overyielding, but the two datasets used in this study did not include such information. However, tree height differences between species imply canopy stratification and hint to architectural differences between species. In addition, different root distributions may result in complementary soil resource use and hence explain overyielding, but direct measurements of roots were not available. However, in addition to complementary resource use, other mechanisms may lead to overyielding, such as effects of mixed litter on nutrient cycling [76], litter decomposition [77], mycorrhizal linkages [20], and pathogens [75], but such interactions are still little understood for mixed forests. Since there is lack of information on those processes, conclusions on such mechanisms remain speculative. 


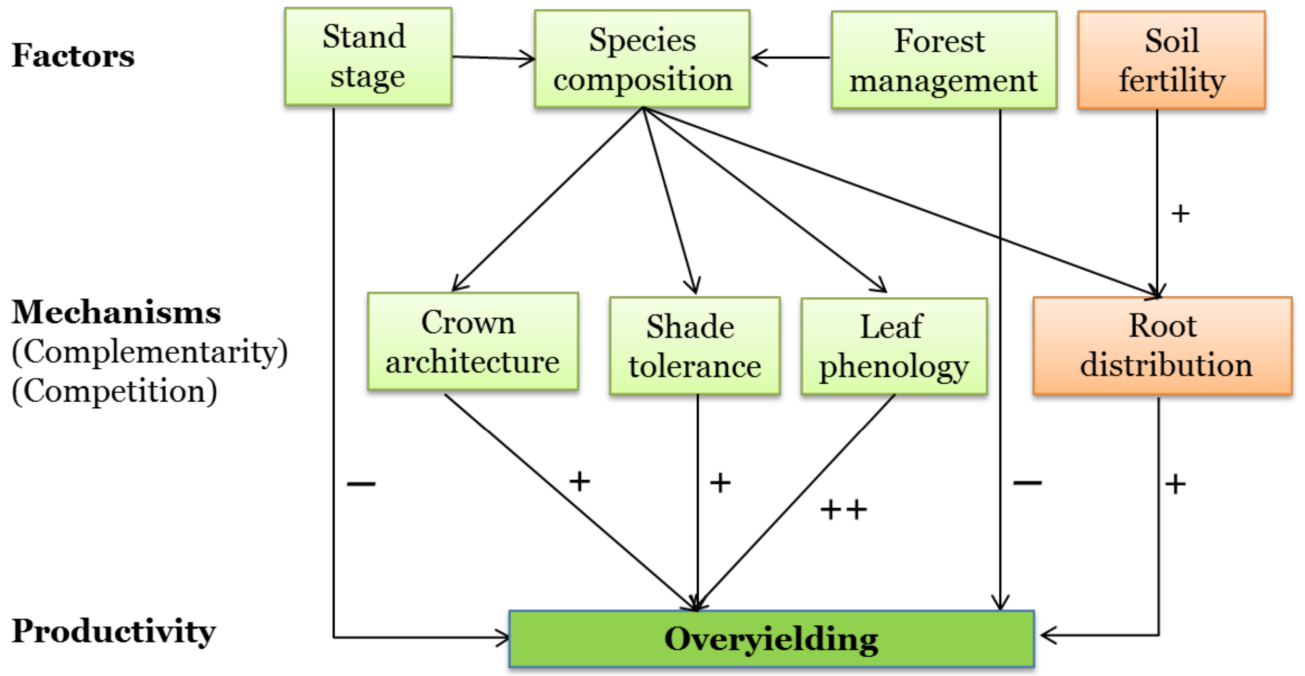

Figure 9. Conceptual framework representing factors and possible mechanisms that could influence on productivity/overyielding discussed in this study. The mechanisms are due to complementarity or reduced competition for light and soils. The discussed mechanisms refer to differences in species characteristics that can allow for complementarity or reduced competition for light and soil resources. The signs along the arrows represent the presence $(+$ or ++$)$ or absence $(-)$ of significant effects detected by the results in this study, but in some cases we lack direct data. ++ , strong effect; +, weak effect; - , no effect [62].

\subsection{Suggestions for Management of Mixed Forests}

The proportion of mixed forest stands in the Netherlands was recently still increasing, as suggested by the inventories of 2003 and 2013 in the Dutch NFI [12]. In total, 695 plots of the 3547 plots in the NFI data of 2013 are mixed species plots according to the mixed stand definition (based on proportion of basal area) presented in our earlier studies [13,14]. These mixed stands include 596 of the five mixtures studied in this study (Table 2). Three of those five mixed stands were predicted to show overyielding: Douglas-fir-beech and pine-oak as shown at stand and species level, and pine-birch as shown at tree level (Figure 7). In the NFI data, there are 629 corresponding monoculture stands of the species in those three mixtures, i.e., Douglas-fir, common beech, Scots pine, pedunculate oak and silver birch. The highest productivity gain is predicted for Douglas-fir mixed with beech: for stands younger than 150 years, Douglas-fir-beech mixtures are predicted to produce up to $3.5 \mathrm{~m}^{3} \mathrm{ha}^{-1}$ year ${ }^{-1}$ more relative to Douglas-fir and beech monocultures [13], and the relative increase in increment is highest on poor soils [14]. Remarkably, the most promising mixture, i.e., Douglas-fir-beech mixture, currently comprises only 16 out of the 3547 plots ([12], Figure 10). The gains in pine-oak mixtures are lower, as they reach approximately $1 \mathrm{~m}^{3} \mathrm{ha}^{-1}$ year $^{-1}$, and again the relative gain is higher for this mixture on poor soils. For the third overyielding mixture, pine-birch, we have no volume gain values, as we only carried out tree-tree relationships (Figure 7). This potential is indicated by the great number of monocultures that are predicted to increase in productivity after mixing, particularly across the sandy soils in the Netherlands (Figure 10). 


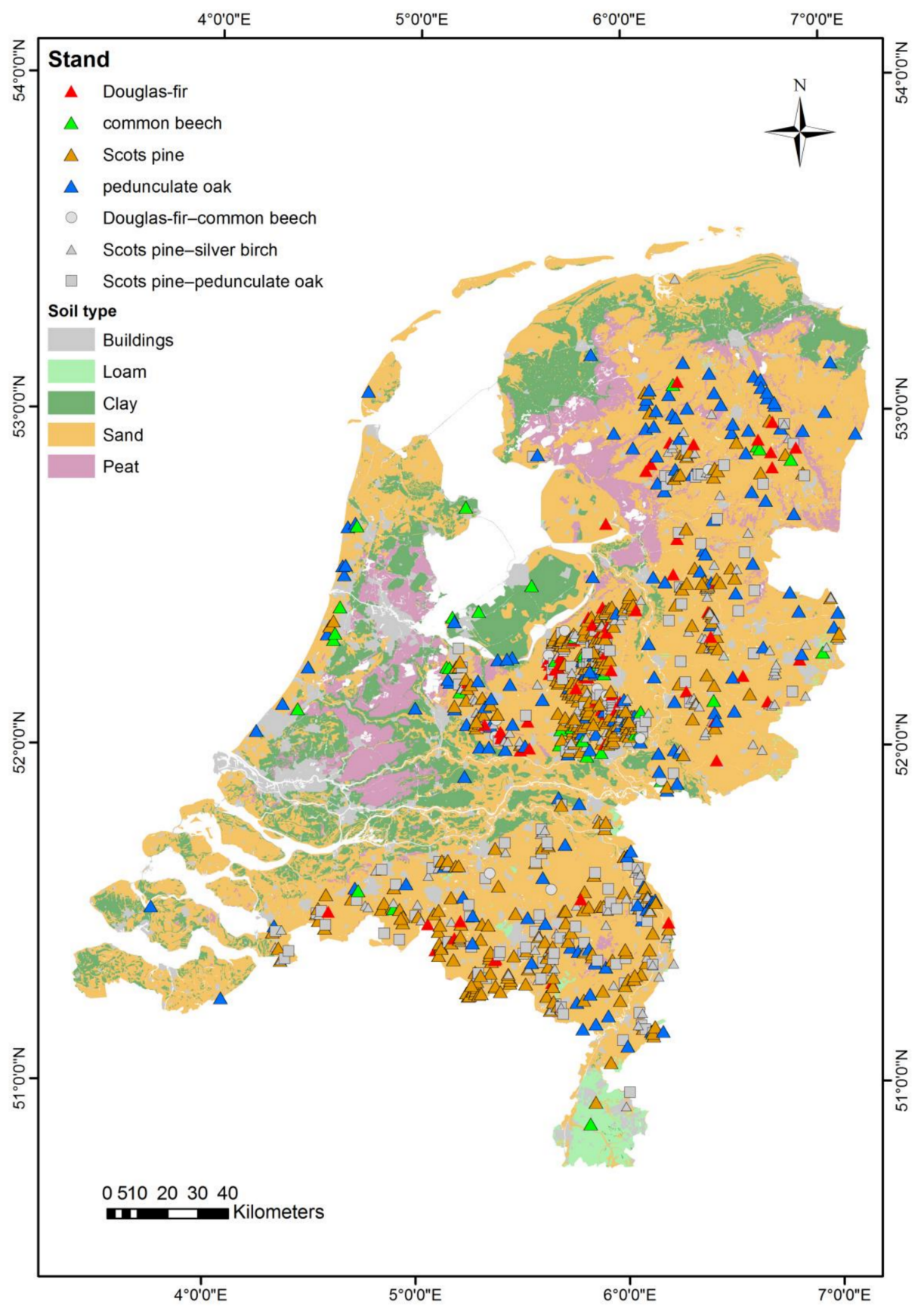

Figure 10. Stand locations that show overyielding or potential overyielding based on the data analysis. Stands on the Dutch soil map are from the Dutch national forest inventory data. Douglas-fir-common beech and Scots pine-pedunculate oak are the mixtures that show overyielding at stand and species level. Scots pine-silver birch is the mixture that shows potential overyielding at tree-level. Common beech, Douglas-fir, Scots pine, pedunculate oak are monoculture stands that are predicted to show overyielding if mixing with Douglas-fir, common beech, pedunculate oak, and Scots pine, respectively [62].

\section{Conclusions}

The increasing importance of mixed-species forests is a reflection of the increasing complexity of societal demands and of climate change upon forest ecosystems, where mixed-species forests are expected to have higher productivity, and higher levels of stability and biodiversity, amongst other ecosystem services. In addition, the increased relevance of mixed forests results from the increasing 
emphasis on the use of spontaneous processes in forest management, as in close-to-nature forestry. This study addressed the question how species mixing influences forest productivity in the Netherlands, and addressed this question at stand, species and tree level. Our study shows that higher productivity, i.e., overyielding, occurred notably in stands with mixtures of evergreen and deciduous species. Moreover, this overyielding was maintained with stand development due to forest management (thinning) aiming at maintaining species mixtures, and was stronger for stands on low fertility soils compared with high fertility soils. It is suggested that differences in leaf phenology in mixed stands are a major determinant of overyielding, but also shade tolerance plays an important role. However, experimental studies will be required for understanding mixing effects on overyielding, and those studies should not only include mechanisms of complementary, but also others, including the role of litter decomposition, pathogens, nutrient cycling and other factors. Finally, this study has identified the competitive interactions on individual tree growth in mixed stands and showed that intra-specific competition is not necessarily stronger than inter-specific competition. Besides, our results imply that light is the most limiting resource for tree growth on most sites in the Netherlands, and that species mixing may alleviate competition for light among neighbouring trees on soils differing in fertility, but especially on poor soils. Based on this, we call for developing forest management strategies that consider the complementarity in resource acquisition of tree species to convert monospecific forests to more productive mixed-species forests.

Author Contributions: H.L., G.M.J.M. and F.J.S. conceived the ideas of this study. H.L., F.J.S., and M.d.R. designed methodology and analysed the data M.-J.S. collected the data. H.L. led the writing of the manuscript. H.L., G.M.J.M., M.d.R., M.-J.S., M.B. and F.J.S. all contributed critically to the drafts and gave final approval for publication.

Funding: H.L. acknowledges financial support from the China Scholarship Council (No. 201306600022), and she also thanks the COST Action FP1206 EuMIXFOR for funding STSM-FP1206-33579 and STSM-FP1206-34833, and the Short Scientific Visits Grant from European Forest Institute, LEB Funding from Wageningen University, and the National Natural Science Foundation of China (Grant No. 31800374) and Qingdao Agricultural University Research Start-Up Fund (Grant No. 1118029).

Acknowledgments: We thank Hans Jansen for compiling data and Leo Goudzwaard for data collection. We are also thankful to Rein de Waal, who provided the soil data of the Netherlands. We would like to express our gratitude to Sonia Condés, Lourens Poorter, Masha van der Sande and Monique Weemstra for discussions and helpful comments on the earlier versions of this manuscript.

Conflicts of Interest: The authors declare no conflict of interest.

\section{References}

1. Agnoletti, M.; Anderson, S. Forest History: International Studies on Socio-Economic and Forest Ecosystem Change, Report No.2 of the IUFRO Task Force on Environmental Change; CABI Publishing: Florence, Italy, 2000; pp. 337-350.

2. Johann, E. Norway Spruce Conversion, Option and Consequences (EFI research report). Available online: http:/ / www.technometre.com/norway-spruce-conversion-options-and-consequences-eurpoean-forestinstitute-reseach.pdf (accessed on 16 November 2018).

3. Machar, I.; Vlckova, V.; Bucek, A.; Vozenilek, V.; Salek, L.; Jerabkova, L. Modelling of climate conditions in forest vegetation zones as a support tool for forest management strategy in European beech dominated forests. Forests 2017, 8, 82. [CrossRef]

4. Krejci, L.; Kolejka, J.; Vozenilek, V.; Machar, I. Application of GIS to empirical windthrow risk model in mountain forested landscapes. Forests 2018, 9, 96. [CrossRef]

5. Agnoletti, M. Man, forestry, and forest landscapes-Trends and perspectives in the evolution of forestry and woodland history research. Schweiz. Z. Forstwes. 2006, 157, 384-392. [CrossRef]

6. Bartelink, H.H. Simulation of Growth and Competition in Mixed Stands of Douglas-Fir and Beech; Landbouwuniversiteit Wageningen: Wageningen, The Netherlands, 1998.

7. Bravo-Oviedo, A.; Pretzsch, H.; Ammer, C.; Andenmatten, E.; Barbati, A.; Barreiro, S.; Brang, P.; Bravo, F.; Coll, L.; Corona, P.; et al. European mixed forests: Definition and research perspectives. For. Syst. 2014, 23, 518-533. [CrossRef] 
8. Chamagne, J.; Tanadini, M.; Frank, D.; Matula, R.; Paine, C.E.T.; Philipson, C.D.; Svátek, M.; Turnbull, L.A.; Volařík, D.; Hector, A. Forest diversity promotes individual tree growth in central European forest stands. J. Appl. Ecol. 2016, 54, 71-79. [CrossRef]

9. Jucker, T.; Bouriaud, O.; Avacaritei, D.; Coomes, D.A. Stabilizing effects of diversity on aboveground wood production in forest ecosystems: Linking patterns and processes. Ecol. Lett. 2014, 17, 1560-1569. [CrossRef] [PubMed]

10. del Río, M.; Pretzsch, H.; Ruíz-Peinado, R.; Ampoorter, E.; Annigöfer, P.; Barbeito, I.; Bielak, K.; Brazaitis, G.; Coll, L. Species interactions increase the temporal stability of community productivity in Pinus sylvestris-Fagus sylvatica mixtures across Europe. J. Ecol. 2017, 105, 1032-1043. [CrossRef]

11. Asensio, I.A.; Bouvet, T.B.A.; Bozzano, M.; Caudullo, G. Forest Europe: State of Europe's forests 2015; Forest Europe, Liaison Unit Madrid: Madrid, Spain, 2015.

12. Schelhaas, M.; Clerkx, A.P.P.M.; Daamen, W.P.; Oldenburger, J.F.; Velema, G.; Schnitger, P.; Schoonderwoerd, H.; Kramer, H. Zesde Nederlandse Bosinventarisatie: Methoden en Basisresultaten; Alterra Wageningen-UR: Wageningen, The Netherlands, 2014.

13. Lu, H.; Mohren, G.M.J.; den Ouden, J.; Goudiaby, V.; Sterck, F.J. Overyielding of temperate mixed forests occurs in evergreen-deciduous but not in deciduous-deciduous species mixtures over time in the Netherlands. For. Ecol. Manag. 2016, 376, 321-332. [CrossRef]

14. Lu, H.; Condés, S.; del Río, M.; Goudiaby, V.; den Ouden, J.; Mohren, G.M.J.; Schelhaas, M.-J.; de Waal, R.; Sterck, F.J. Species and soil effects on overyielding of tree species mixtures in the Netherlands. For. Ecol. Manag. 2018, 409, 105-118. [CrossRef]

15. Pretzsch, H.; Zenner, E.K. Toward managing mixed-species stands: From parametrization to prescription. For. Ecosyst. 2017, 4, 19. [CrossRef]

16. Tilman, D. The ecological consequences of changes in biodiversity: A search for general principles 101. Ecology 1999, 80, 1455-1474.

17. Forrester, D.I. The spatial and temporal dynamics of species interactions in mixed-species forests: From pattern to process. For. Ecol. Manag. 2014, 312, 282-292. [CrossRef]

18. Hynynen, J.; Repola, J.; Mielikäinen, K. The effects of species mixture on the growth and yield of mid-rotation mixed stands of Scots pine and silver birch. For. Ecol. Manag. 2011, 262, 1174-1183. [CrossRef]

19. Ammer, C. Diversity and forest productivity in a changing climate. New Phytol. 2018. [CrossRef] [PubMed]

20. Kelty, M.J. Comparative productivity of monocultures and mixed-species stands. In The Ecology and Silviculture of Mixed-Species Forests; Springer: New York, NY, USA, 1992; pp. 125-141.

21. Jucker, T.; Bouriaud, O.; Coomes, D.A. Crown plasticity enables trees to optimize canopy packing in mixed-species forests. Funct. Ecol. 2015, 29, 1078-1086. [CrossRef]

22. Pretzsch, H. Canopy space filling and tree crown morphology in mixed-species stands compared with monocultures. For. Ecol. Manag. 2014, 327, 251-264. [CrossRef]

23. Kelty, M.J. Productivity of New England hemlock/hardwood stands as affected by species composition and canopy structure. For. Ecol. Manag. 1989, 28, 237-257. [CrossRef]

24. Longuetaud, F.; Piboule, A.; Wernsdörfer, H.; Collet, C. Crown plasticity reduces inter-tree competition in a mixed broadleaved forest. Eur. J. For. Res. 2013, 132, 621-634. [CrossRef]

25. Williams, L.J.; Paquette, A.; Cavender-Bares, J.; Messier, C.; Reich, P.B. Spatial complementarity in tree crowns explains overyielding in species mixtures. Nat. Ecol. Evol. 2017, 1, 63. [CrossRef] [PubMed]

26. Ma, Z.; Chen, H.Y. Effects of species diversity on fine root productivity increase with stand development and associated mechanisms in a boreal forest. J. Ecol. 2017, 105, 237-245. [CrossRef]

27. Thurm, E.A.; Biber, P.; Pretzsch, H. Stem growth is favored at expenses of root growth in mixed stands and humid conditions for Douglas-fir (Pseudotsuga menziesii) and European beech (Fagus sylvatica). Trees 2016, 31, 349-365. [CrossRef]

28. Brassard, B.W.; Chen, H.Y.H.; Cavard, X.; Laganière, J.; Reich, P.B.; Bergeron, Y.; Paré, D.; Yuan, Z. Tree species diversity increases fine root productivity through increased soil volume filling. J. Ecol. 2013, 101, 210-219. [CrossRef]

29. Ma, Z.; Chen, H.Y.H. Positive species mixture effects on fine root turnover and mortality in natural boreal forests. Soil Biol. Biochem. 2018, 121, 130-137. [CrossRef] 
30. Reyer, C.; Lasch, P.; Mohren, G.M.J.; Sterck, F.J. Inter-specific competition in mixed forests of Douglas-fir (Pseudotsuga menziesii) and common beech (Fagus sylvatica) under climate change-A model-based analysis. Ann. For. Sci. 2010, 67, 805. [CrossRef]

31. Forrester, D.I.; Theiveyanathan, S.; Collopy, J.J.; Marcar, N.E. Enhanced water use efficiency in a mixed Eucalyptus globulus and Acacia mearnsii plantation. For. Ecol. Manag. 2010, 259, 1761-1770. [CrossRef]

32. Thomas, F.; Bögelein, R.; Werner, W. Interaction between Douglas fir and European beech: Investigations in pure and mixed stands. Forstarchiv 2015, 86, 83-91.

33. Hendriks, C.; Bianchi, F. Root density and root biomass in pure and mixed forest stands of Douglas-fir and Beech. Neth. J. Agric. Sci. 1995, 43, 321-331.

34. Manso, R.; Morneau, F.; Ningre, F.; Fortin, M. Effect of climate and intra-and inter-specific competition on diameter increment in beech and oak stands. Forestry 2015, 88, 540-551. [CrossRef]

35. Forrester, D.I.; Bauhus, J.; Cowie, A.L.; Vanclay, J.K. Mixed-species plantations of Eucalyptus with nitrogen-fixing trees: A review. For. Ecol. Manag. 2006, 233, 211-230. [CrossRef]

36. Poorter, H.; Niklas, K.J.; Reich, P.B.; Oleksyn, J.; Poot, P.; Mommer, L. Biomass allocation to leaves, stems and roots: Meta-analyses of interspecific variation and environmental control. New Phytol. 2012, 193, 30-50. [CrossRef] [PubMed]

37. Bertness, M.D.; Callaway, R. Positive interactions in communities. Trends Ecol. Evol. 1994, 9, $191-193$. [CrossRef]

38. Tilman, D. The resource-ratio hypothesis of plant succession. Am. Nat. 1985, 125, 827-852. [CrossRef]

39. Toïgo, M.; Vallet, P.; Perot, T.; Bontemps, J.-D.; Piedallu, C.; Courbaud, B. Overyielding in mixed forests decreases with site productivity. J. Ecol. 2015, 103, 502-512. [CrossRef]

40. del Río, M.; Sterba, H. Comparing volume growth in pure and mixed stands of Pinus sylvestris and Quercus pyrenaica. Ann. For. Sci. 2009, 66, 1-11.

41. Pretzsch, H.; Bielak, K.; Block, J.; Bruchwald, A.; Dieler, J.; Ehrhart, H.-P.; Kohnle, U.; Nagel, J.; Spellmann, H.; Zasada, M.; et al. Productivity of mixed versus pure stands of oak (Quercus petraea (Matt.) Liebl. and Quercus robur L.) and European beech (Fagus sylvatica L.) along an ecological gradient. Eur. J. For. Res. 2013, 132, 263-280. [CrossRef]

42. Forrester, D.I.; Kohnle, U.; Albrecht, A.T.; Bauhus, J. Complementarity in mixed-species stands of Abies alba and Picea abies varies with climate, site quality and stand density. For. Ecol. Manag. 2013, 304, $233-242$. [CrossRef]

43. Jucker, T.; Bouriaud, O.; Avacaritei, D.; Dănilă, I.; Duduman, G.; Valladares, F.; Coomes, D.A. Competition for light and water play contrasting roles in driving diversity-productivity relationships in Iberian forests. J. Ecol. 2014, 102, 1202-1213. [CrossRef]

44. Thurm, E.A.; Pretzsch, H. Improved productivity and modified tree morphology of mixed versus pure stands of European beech (Fagus sylvatica) and Douglas-fir (Pseudotsuga menziesii) with increasing precipitation and age. Ann. For. Sci. 2016, 73, 1047-1061. [CrossRef]

45. Pretzsch, H.; Block, J.; Dieler, J.; Dong, P.H.; Kohnle, U.; Nagel, J.; Spellmann, H.; Zingg, A. Comparison between the productivity of pure and mixed stands of Norway spruce and European beech along an ecological gradient. Ann. For. Sci. 2010, 67, 712. [CrossRef]

46. Pretzsch, H.; Schuetze, G.; Uhl, E. Resistance of European tree species to drought stress in mixed versus pure forests: Evidence of stress release by inter-specific facilitation. Plant Biol. 2013, 15, 483-495. [CrossRef] [PubMed]

47. del Río, M.; Schütze, G.; Pretzsch, H. Temporal variation of competition and facilitation in mixed species forests in Central Europe. Plant Biol. 2014, 16, 166-176. [CrossRef] [PubMed]

48. Lebourgeois, F.; Gomez, N.; Pinto, P.; Mérian, P. Mixed stands reduce Abies alba tree-ring sensitivity to summer drought in the Vosges mountains, western Europe. For. Ecol. Manag. 2013, 303, 61-71. [CrossRef]

49. Condés, S.; Río, M. Climate modifies tree interactions in terms of basal area growth and mortality in monospecific and mixed Fagus sylvatica and Pinus sylvestris forests. Eur. J. For. Res. 2015, 134, 1-14. [CrossRef]

50. del Río, M.; Condés, S.; Pretzsch, H. Analyzing size-symmetric vs. size-asymmetric and intra- vs. inter-specific competition in beech (Fagus sylvatica L.) mixed stands. For. Ecol. Manag. 2014, 325, 90-98. [CrossRef] 
51. Schwinning, S.; Weiner, J. Mechanisms determining the degree of size asymmetry in competition among plants. Oecologia 1998, 113, 447-455. [CrossRef] [PubMed]

52. Hara, T. Mode of competition and size-structure dynamics in plant communities. Plant Species Biol. 1993, 8 , 75-84. [CrossRef]

53. Oliver, C.D.; Larson, B.C. Forest Stand Dynamics: Updated Edition; John Wiley and Sons: New York, NY, USA, 1996.

54. Ryan, M.; Binkley, D.; Fownes, J. Age-related decline in forest productivity. Adv. Ecol. Res. 1997, 27, $213-262$.

55. Jansen, J.J.; Sevenster, J.; Faber, J. Opbrengsttabellen voor Belangrijke Boomsoorten in Nederland; Institute for Forestry and Nature Research: Wageningen, The Netherlands, 1996; p. 202.

56. Drössler, L.; Agestam, E.; Bielak, K.; Dudzinska, M.; Koricheva, J.; Liziniewicz, M.; Löf, M.; Mason, B.; Pretzsch, H.; Valkonen, S.; et al. Over- and underyielding in time and space in experiments with mixed stands of Scots pine and Norway spruce. Forests 2018, 9, 18. [CrossRef]

57. Puettmann, K.J.; Wilson, S.M.; Baker, S.C.; Donoso, P.J.; Drössler, L.; Amente, G.; Harvey, B.D.; Knoke, T.K.; Lu, Y.; Nocentini, S.; et al. Silvicultural alternatives to conventional even-aged forest management-what limits global adoption? For. Ecosyst. 2015, 2, 8. [CrossRef]

58. Den Ouden, J.; Mohren, G. Thematic Collection: FEM Growth and Yield Data; DANS: Wageningen, The Netherlands, 2016.

59. Forrester, D.I.; Pretzsch, H. Tamm Review: On the strength of evidence when comparing ecosystem functions of mixtures with monocultures. For. Ecol. Manag. 2015, 356, 41-53. [CrossRef]

60. Pretzsch, H.F.; David, I.; Rotzer, T. Representation of species mixing in forest growth models: A review and perspective. Ecol. Model. 2015, 313, 276-292. [CrossRef]

61. Hengl, T.; de Jesus, J.M.; Heuvelink, G.B.M.; Gonzalez, M.R.; Kilibarda, M.; Blagotić, A.; Wei, S.; Wright, M.N.; Geng, X.; Bauer-Marschallinger, B.; et al. SoilGrids250 m: Global gridded soil information based on machine learning. PLoS ONE 2016, 12, e0169748.

62. Lu, H. Species Mixing Effects on Forest Productivity in the Netherlands; Wageningen University: Wageningen, The Netherlands, 2017.

63. Dekker, M.; van Breugel, M.; Sterck, F.J. Effective height development of four co-occurring species in the gap-phase regeneration of Douglas fir monocultures under nature-oriented conversion. For. Ecol. Manag. 2007, 238, 189-198. [CrossRef]

64. Janse-Ten Klooster, S.H.; Thomas, E.J.; Sterck, F.J. Explaining interspecific differences in sapling growth and shade tolerance in temperate forests. J. Ecol. 2007, 95, 1250-1260. [CrossRef]

65. Oliver, C.D. Forest organization, management, and policy. In Maintaining Biodiversity in Forest Ecosystems; Hunter, M., Ed.; Cambridge University Press: New York, NY, USA, 1999; pp. 556-596.

66. Latham, P.A.; Zuuring, H.R.; Coble, D.W. A method for quantifying vertical forest structure. For. Ecol. Manag. 1998, 104, 157-170. [CrossRef]

67. Pretzsch, H.; del Río, M.; Ammer, C.; Avdagic, A.; Barbeito, I.; Bielak, K.; Brazaitis, G.; Coll, L.; Dirnberger, G.; Fabrika, M.; et al. Growth and yield of mixed versus pure stands of Scots pine (Pinus sylvestris L.) and European beech (Fagus sylvatica L.) analysed along a productivity gradient through Europe. Eur. J. For. Res. 2015, 134, 927-947. [CrossRef]

68. Coates, K.D.; Lilles, E.B.; Astrup, R. Competitive interactions across a soil fertility gradient in a multispecies forest. J. Ecol. 2013, 101, 806-818. [CrossRef]

69. Cavard, X.; Bergeron, Y.; Chen, H.Y.H.; Paré, D.; Laganière, J.; Brassard, B. Competition and facilitation between tree species change with stand development. Oikos 2011, 120, 1683-1695. [CrossRef]

70. Baribault, T.W.; Kobe, R.K. Neighbour interactions strengthen with increased soil resources in a northern hardwood forest. J. Ecol. 2011, 99, 1358-1372. [CrossRef]

71. Trinder, C.J.; Brooker, R.W.; Davidson, H.; Robinson, D. A new hammer to crack an old nut: Interspecific competitive resource capture by plants is regulated by nutrient supply, not climate. PLoS ONE 2012, 7, e29413. [CrossRef] [PubMed]

72. Coates, K.D.; Canham, C.D.; LePage, P.T. Above-versus below-ground competitive effects and responses of a guild of temperate tree species. J. Ecol. 2009, 97, 118-130. [CrossRef]

73. Perot, T.; Picard, N. Mixture enhances productivity in a two-species forest: Evidence from a modeling approach. Ecol. Res. 2012, 27, 83-94. [CrossRef] 
74. Weemstra, M. Belowground Uptake Strategies: How Fine-Root Traits Determine Tree Growth; Wageningen University: Wageningen, The Netherlands, 2017.

75. Hantsch, L.; Bien, S.; Radatz, S.; Braun, U.; Auge, H.; Bruelheide, H. Tree diversity and the role of non-host neighbour tree species in reducing fungal pathogen infestation. J. Ecol. 2014, 102, 1673-1687. [CrossRef] [PubMed]

76. Dawud, S.; Vesterdal, L.; Raulund-Rasmussen, K. Mixed-species effects on soil C and N stocks, C/N ratio and $\mathrm{pH}$ using a transboundary approach in adjacent common garden Douglas-fir and beech stands. Forests 2017, 8, 95. [CrossRef]

77. Setiawan, N.N.; Vanhellemont, M.; De Schrijver, A.; Schelfhout, S.; Baeten, L.; Verheyen, K. Mixing effects on litter decomposition rates in a young tree diversity experiment. Acta Oecologica 2016, 70, 79-86. [CrossRef]

2018 by the authors. Licensee MDPI, Basel, Switzerland. This article is an open access article distributed under the terms and conditions of the Creative Commons Attribution (CC BY) license (http://creativecommons.org/licenses/by/4.0/). 